\title{
Száz éve született Páter Károly
}

Páter Károly 1900. március 31-én született Kolozsváron. A természetszeretetét, a természettudományok iránti tiszteletét és vonzódását a szülői házból hozta magával. Édesapja, Páter Béla, a botanika elismert tudósa a kolozsmonostori Gazdasági Akadémia növénytan tanára, igazgatója, a kolozsvári Gyógynövény-kísérleti Intézet vezetője volt. Páter Károly gyermekkorát szülővárosában töltötte. A gimnázium nyolc osztályát az unitárius kollégiumban végezte el, 1918 márciusában érettségizett jeles eredménnyel.

1918. március 15-én bevonult katonának, Déltirolba került. A forradalom kitörése, illetve alakulata felbomlása után hazatért Kolozsvárra. 1920 márciusáig kémiai tanulmányokat folytatott a még müködő kolozsvári egyetemen.

1920 márciusában Budapestre repatriált és a Műegyetemre iratkozott be, ahol 1926ban vegyészmérnöki diplomát szerzett. A tehetséges vegyészre itt figyelt fel 'Sigmond Elek, aki maga mellé vette munkatársnak a Müegyetem Talajtani Laboratóriumába. 'Sigmond professzor tanszékén 1929-ig volt tanársegéd, s bekapcsolódott a nemzetközi viszonylatban is legkorszerübb talajtani kutatásokba, részletesebben a hazai szikes talajokat tanulmányozta. A 'Sigmond tanszékén szerzett tapasztalatai tették számára lehetővé, hogy a későbbi mostohább körülmények között is lépést tudott tartani a talajtani tudomány fejlődésével. A müegyetemi évek meghatározták további életútját, mivel itt érlelödött meg benne a talajtan és agrokémia iránti vonzódása. 'Sigmond Elek munkatársaként dolgozott az Országos Chemiai Intézet akkor megszervezett Talajkémiai Osztályán is.

Sajnos, az 1920-as évek végének gazdasági körülményei nem kedveztek a talajtani kutatások bővítésének, ekkor anyagi okok miatt Páter Károly a keszthelyi Gazdasági Akadémiára került, ahol a Kémiai Tanszéken bekapcsolódott a mütrágyázási és talajmeszezési kísérletekbe, az ország különböző részein beállított kísérletek talajvizsgálatainak végzésébe. Így hasznos tapasztalatokat szerezhetett az ország rendkívül változatos talajviszonyairól. A Növénytermesztési Tanszéken ellátta az összes talajvizsgálatot. Közremüködött a Kémiai Tanszék oktatási munkájában is, a kémiai gyakorlatokat vezette.

1931-ben Szegedre került az Alföldi Mezőgazdasági Intézet Talajtani és Agrokémiai Osztályára, ahol Herke Sándor mellett tanulmányozta a szikes talajokat, majd 1931-ben a szarvasi Középfokú Gazdasági Tanintézethez helyezték át. Itt rövid idő alatt tanári gyakorlatra tett szert és a kémiai oktatás terén eredményei elismerésre találtak. Kilenc évig volt a mezőgazdasági vegytan tanára, s közben foglalkozott a Szarvas környéki szikes talajok felmérésével és javításuk lehetőségeivel. Számos ismeretterjesztő ill. szakelöadást tartott a kisgazdáknak az ottani Földmunkás Szövetkezetben. Szarvason kezdte el az öntözés talajra gyakorolt hatásának vizsgálatát. Megfelelö felszerelés 
hiányában azonban megfigyeléseit és elgondolásait nem tudta tudományos szakirodalmi működés formájában is értékessé tenni, mint ahogy azt szerette volna.

1940-ben újra a keszthelyi Gazdasági Akadémiára került, s megbízták a Kémiai Tanszék vezetésével. Két évig tartotta a kémiai előadásokat, gyakorlatokat és vezette az akadémiai pincegazdaságot is. 1942 nyarán áthelyezték a mosonmagyaróvári Gazdasági Akadémiára, ahol rendkívüli tanárnak nevezték ki. Az Akadémia Mezőgazdasági Főiskolává történt átszervezésekor, 1942-ben átminősítették akadémiai rendes tanárrá és új Mezőgazdasági Kémiai Tanszék megszervezésével és irányításával bízták meg.

Ebben az időszakban kapcsolódott be a Földtani Intézet által szervezett átnézetes talajismereti talajtérképezési munkálatokba. Kreybig Lajos irányításával 1941-ben a kapuvári, 1942-ben a sopronkeresztúri (ma: Deutschkreutz - Ausztria) talajfelvételezési lapokat készítette el.

Az Agrártudományi Egyetem megalakulásakor, 1945-ben a mosonmagyaróvári fóiskola az új intézmény egyik osztályaként müködött tovább, a Kémiai Tanszék nyilvános rendkívüli tanárának nevezték ki, 1948-ban pedig megbízták az újonnan megalakult tanszék vezetésével. 1949 áprilisában az Agrártudományi Egyetem Talajtani Tanszékének vezetőjévé nevezték ki. Több mint másfél évtizedig - haláláig - irányította a tanszék oktató-kutató munkáját.

1949 augusztusában a Földművelésügyi Miniszter az újonnan szervezett Agrokémiai Intézet igazgatói teendőinek ellátásával bízta meg. E tisztséget 1951-ig, az Agrártudományi Egyetem Gödöllöre történő költözéséig látta el.

1951-ben kinevezték az Agrártudományi Egyetem rektorává. Előkészíti az egyetemi oktatás reformjának nagy munkáját, és végrehajtja az egyetem Gödöllőre való költöztetését. Eközben, mint közéleti személyiség, számos egyéb funkciót is ellátott. Oktatókutató munkáján kívül számtalan, gyakran erejét felülmúló egyetemi és más feladatot vállalt magára. 1941-től az Állandó Központi Talajjavító Bizottság tagjaként ráháruló feladatokat is ellátta.

Tagja volt a Nemzetközi Talajtani Társaságnak, az MTA Talajtani és Agrokémiai Intézete Tudományos Tanácsának, elnöke a talaj termékenységével foglalkozó Országos Távlati Tudományos Tervfeladat Koordinációs Bizottságnak. Az MTA megbízásából közremüködött a Magyar Agrártudományi Egyesület megalakításában, az alakuló ülésen az Egyesület fötitkárává választották, mely tisztséget 1955-ig töltötte be. Az Egyesület feladatának az elmélet és gyakorlat közötti kapcsolat ápolását, erősítését tekintette.

Társelnöke volt a Magyar Talajtani Társaságnak. Az „Agrokémia és Talajtan” című folyóirat megindításától kezdve 10 éven keresztül főszerkesztője, majd haláláig szerkesztőbizottsági tagja volt.

Az egyetem vezető professzoraként részt vett több nemzetközi rendezvényen, így a Nemzetközi Talajtani Társaság 1956. évi párizsi kongresszusán, az 1959. évi prágai talajtani konferencián, az Academia Georgofili kétszázéves jubileumán Firenzében.

Az említetteken kívül a kormány vezetői még számos jelentős és megtisztelő feladattal látták el Páter Károlyt, melyeknek a legteljesebb mértékben igyekezett eleget tenni. Legnagyobb hatású volt az a tevékenysége, amelyet a mezőgazdasági tudomány és agrár-felsőoktatás terén, mint rektor és tanszékvezető fejtett ki.

Az Agrártudományi Egyetem rektori teendőit 1951-től 1955-ig látta el. Az Egyetem egészét érintő szervezeti változások (1952-ben az Erdőgazdasági és az Állatorvostudományi, 1953-ban pedig a Kertgazdaságtudományi Kar önállósult) után teljesen új fejlesztési koncepcióra volt szükség, ennek kidolgozásának irányítása a rektorra hárult. 
Az Egyetemen bevezették a specializálást, 1951-ben agrár-közgazdasági, agronómiai, állattenyésztési és gépesítési szakok indultak már az első évfolyamtól, majd ezek a szakok fejlődtek karokká, melyek hosszabb időn át meghatározói voltak az oktatás rendjének, a képzési területeknek.

Páter Károly rektorsága idején az oktatás- és kutatásszervezés, valamint számos egyéb állami megbízás mellett is folyamatosan tartotta talajtani előadásait. Három karon (Agronómiai, Állattenyésztési és Közgazdasági Karon) oktatta a talajtant. Előadásai a 'Sigmond-iskola szellemét tükrözték, azok felépítésére, közérthető magyaros stílusára nagy gondossággal ügyelt. Előadásait - különösen a talajképzö tényezők és egyes talajtípusok ismertetésénél - az ökológiai szemlélet, a környezet, az ökoszisztéma megóvására irányuló felelősségérzet hatotta át. Az egyes tárgyköröknél sose feledkezett meg a tudománytörténeti, néprajzi, nyelvészeti vonatkozásokról sem. Egyetemi jegyzeteit (A talajtan geológiai alapjai, 1955; Talajtan, I., II. rész, 1957) a lényegre törő tömörség jellemezte.

Az előadások és gyakorlatok óraszáma alapján a talajtan jelentősége, súlya jóval nagyobb volt, mint jelenleg. Az 1956/57. tanévben az Agronómiai Karon a 3. félévben heti $2+2$ óra ( 2 óra előadás, 2 óra gyakorlat), a 4 . félévben $3+2$ óra, az Agrár-közgazdasági Karon a 3.félévben heti $2+2$ óra, a 4 . félévben szintén heti $2+2$ óra volt biztosítva a talajtan oktatásához. Az előadásokat a nappali tagozaton gyakorlatilag teljes egészében Páter Károly tartotta, csak kivételes esetben bízta valamelyik munkatársára. Fakultatív tantárgy volt a Talajjavítás két féléven keresztül heti 2 órában.

A Talajtan c. tantárgy oktatásának szerves részét képezte a tavaszi (vagy nyári) terepgyakorlat, amely jól egészítette ki az előadások anyagát. A talajtani üzemi gyakorlatoknak célja és feladata az volt, hogy a hallgatóságot önálló felelősségteljes szakmai munkára nevelje. A hallgatók elkészítették egy állami gazdaság, vagy egyetemi tangazdaság egy adott területének üzemi talajtani térképét. Ezeken a gyakorlatokon a hallgatók megtanulták, hogy a termesztési gyakorlatban hogyan, milyen feladatok megoldásához lehet felhasználni a talajtani ismereteket. Páter professzor gyakran maga is meglátogatta ezeket a gyakorlatokat.

Az oktatás területén érdemei közül kiemelkedő a talajtani szakmérnökképzés kezdeményezése, mellyel a hazai talajtani szakemberképzést kívánta megalapozni. Összeállította a „Talajtani és agrokémiai” szakmérnöki szak tematikáját. E szakon mind a talajtan, mind az agrokémia c. tárgy előadásait - néhány egyetemi és egyetemen kívüli előadó bekapcsolásával - Páter Károly adta le. A szakmérnöki program kidolgozása komoly munkát jelentett. Nagyon tanulságosak voltak a szakmérnökképzés keretében az általa vezetett tanulmányutak. Viszonylag sokat vállalt az oktatási feladatokból, heti 12 óra előadást tartott, melyeknek anyagát gondosan rendszerezte, s évről-évre újabb tudományos eredménnyel egészítette ki. Kezdeményezte az öntözéses gazdálkodási szakmérnöki szak talajtani oktatásának bevezetését.

Páter Károly nagy súlyt helyezett a tanszék könyvtárának, szakirodalmi gyüjteményének kialakítására, folyamatos bővítésére. Az Egyetem Gödöllöre történt költözésekor magával hozta a 'Sigmond-féle különlenyomat-gyüjtemény megmaradt, de még így is tekintélyesnek mondható részét. A tanszék jelenlegi közet-, ásvány- és monolitgyüjteményét is az ő munkássága alapozta meg.

Páter Károly tevékenységét elválaszthatatlanul hatotta át a nevelőmunka. Az oktatóés nevelőmunka szerves kapcsolatát hirdette, ami több feladat vállalását és nagyobb felelősséget kíván az oktatóktól. A tudományos ismeretek átadása mellett nem szabad 
szem elől téveszteni az életre való nevelést. „Professzoraink tudására, ifjúságunk lendületére és lelkesedésére támaszkodva kell törekedni a tanulmányi idő optimális kihasználására. Az országnak nemcsak képzett, hanem kiválóan képzett szakemberekre van szüksége."

Mint rektor és, mint tanszékvezető is az oktatástól elválaszthatatlannak tartotta a nevelőmunkát. Gyakran hangsúlyozta, hogy az egyetemi oktatásnak a hivatás szeretetére való nevelést is szolgálnia kell.

Oktató- és tudományszervező tevékenysége mellett rendszeresen végzett kutatómunkát, és irányította munkatársai kutatási témáit. Két fontosabb átfogó kutatási témán dolgozott „Mésztelen, semleges körüli, gyengén lúgos és erősen lúgos szikes talajok javitása kémiai javítóanyagokkal az öntözés által megszabott hidrológiai viszonyok között” és „Magyarország talajtakarója földrajzi elterjedési törvényszerüségeinek vizsgálata, főbb jellegzetes talajtípusok, talajtájak genetikai feldolgozása." Eredményeiből két tanulmányt az 1964-ben tartott bukaresti Nemzetközi Talajtani Kongresszusra szeretett volna benyújtani. Fő célkitüzése a szikesek kialakulási folyamatainak és hasznosíthatósága fokozatainak tisztázása volt. Mind tudományos, mind gyakorlati szempontból nagy jelentőségüek szikjavítási kísérletei. Előadásaiban és tanulmányaiban hangsúlyozta, hogy a mésszel, gipsszel, lignittel végzett javítási eljárásokat igyekezni kell összekapcsolni vízrendezéssel, illetve a talajok kimosásával. A tartós javulás alapfeltétele, hogy a kationkicserélődés útján oldatba került nátrium, illetve nátriumsók a talajból kimosódhassanak. A kimosódást elősegíti, hogy a kationkicserélődés következtében megjavul a talaj felsőbb szintjeinek vízáteresztő képessége. Ahol valamilyen ok miatt (magas talajvízállás, a feltalaj túl nagy sótartalma stb.) ez a lemosódás nem mehet végbe, ott a talajjavítástól nem várhatunk kellö eredményt. Ez irányú szabadföldi kísérletei, laboratóriumi vizsgálatai és adatértékelései voltak utolsó munkái.

Érdeklődésének középpontja, kedvenc témája a szikesek genetikája, tulajdonságainak alakulása és javításuk kérdése volt. A hortobágyi és hajdúsági szikesek vizsgálata során, talajfelvételezési munkáknál minden részletre kiterjedően, nagy pontossággal sorolta be az osztályozási rendszerbe az egyes típusokat, altípusokat és változatokat. Tudományos érdeklődésében megkülönböztetett helyet foglalt el az öntözés talajra gyakorolt hatása és a másodlagos szikesedés, valamint a müvelés hatása a talaj pórusrendszerére.

Emberi magatartása, vonzó tulajdonságai miatt munkatársai, tanítványai tisztelték és szerették. Elfoglaltságai ellenére mindig lehetett hozzáfordulni, önzetlenül segített. Különösen a több napos kiszállások alkalmával tanulhattak töle munkatársai, ekkor kaptunk képet intellektusáról, müvészeti, filozófiai nézeteiről, tájékozottságáról.

Tudományos szemléletét, a kutatói felelősségről és lelkiismeretességről vallott eszméit a vezetése alatt dolgozó aspiránsok és oktatók szellemiségébe is átültette. Eredményes és közvetlen tevékenységet fejtett ki a tudományos továbbképzés területén, aminek bizonyítéka, hogy szükre szabott tanszéki létszámkerete ellenére is 6 munkatársa szerzett irányítása mellett kandidátusi tudományos fokozatot. Tanítását, útmutatásait, buzdítását és példáját követve több tanítványa, talajtanos szakemberként szerzett magának elismerést, köztük Hargitai László, Gerei László, Nyíri László, Várallyay György stb.

Józan megfontoltságával, bölcs humanitásával - amely rektori és tanszékvezetői tevékenységét áthatotta - elnyerte kollégáinak és, tanítványainak őszinte megbecsülését. A bizottsági üléseken - az értékes gondolatokat kiemelve - jó érzékkel csillapította le az 
egymásnak feszülő szenvedélyeket. Az általa vezetett rendezvények után, a közismert nyugalmával és tapasztalatával hozott döntéseit a vitában ellentétes nézeteket képviselö szakemberek is megértéssel fogadták el.

A szinte egyedül szakmájának élő ember, szerény magatartásával, a legszélesebb körü tiszteletet és elismerést váltotta ki. Az egyetem szervezésében, megalapozásában, a mezőgazdasági szakoktatás és kutatás irányának kijelölésében elévülhetetlen és mindenkor megbecsült érdemeket szerzett. Olyan általános tisztelet és szeretet övezte, melyhez mérhető ritkán fordul elö. Tudományának fanatikus szeretete és a legszélesebb körü segítökészség jellemezte. Szakterületére ma is komoly befolyást gyakorol, hatása tanítványain keresztül ma is elevenen él.

Egész élettevékenysége a jelen fiatal szakemberei elé is példaképül állítható, mert kitünő harmóniában egyesítette a komoly elmélyült kutatót, az eredményes oktatót és tudományos szervezőt.

A tudós és kivételes képességekkel rendelkező ember emlékét őrzi a Páter Károly út és a Páter Károly Emlékérem. Volt hallgatói, tanítványai az évfolyam-találkozók alkalmával az Egyetem föépületén elhelyezett emléktábla megkoszorúzásával fejezik ki Páter Károly iránti tiszteletüket és nagyrabecsülésüket.

FEKETE JÓZSEF

Szent István Egyetem Mezőgazdaság- és Környezettudományi Kar, Gödöllő 